\title{
Understanding land surface response to changing South Asian monsoon in a warming climate
}

\author{
M. V. S Ramarao, R. Krishnan, J. Sanjay, and T. P. Sabin \\ Centre for Climate Change Research, Indian Institute of Tropical Meteorology, Pune, India \\ Correspondence to: J. Sanjay (sanjay @ tropmet.res.in)
}

Received: 5 April 2015 - Published in Earth Syst. Dynam. Discuss.: 6 May 2015

Revised: 26 August 2015 - Accepted: 27 August 2015 - Published: 11 September 2015

\begin{abstract}
Recent studies have drawn attention to a significant weakening trend of the South Asian monsoon circulation and an associated decrease in regional rainfall during the last few decades. While surface temperatures over the region have steadily risen during this period, most of the CMIP (Coupled Model Intercomparison Project) global climate models have difficulties in capturing the observed decrease of monsoon precipitation, thus limiting our understanding of the regional land surface response to monsoonal changes. This problem is investigated by performing two long-term simulation experiments, with and without anthropogenic forcing, using a variable resolution global climate model having high-resolution zooming over the South Asian region. The present results indicate that anthropogenic effects have considerably influenced the recent weakening of the monsoon circulation and decline of precipitation. It is seen that the simulated increase of surface temperature over the Indian region during the post-1950s is accompanied by a significant decrease of monsoon precipitation and soil moisture. Our analysis further reveals that the land surface response to decrease of soil moisture is associated with significant reduction in evapotranspiration over the Indian land region. A future projection, based on the representative concentration pathway 4.5 (RCP4.5) scenario of the Intergovernmental Panel on Climate Change (IPCC), using the same high-resolution model indicates the possibility for detecting the summer-time soil drying signal over the Indian region during the 21 st century in response to climate change. Given that these monsoon hydrological changes have profound socio-economic implications the present findings provide deeper insights and enhance our understanding of the regional land surface response to the changing South Asian monsoon. While this study is based on a single model realization, it is highly desirable to have multiple realizations to establish the robustness of the results.
\end{abstract}

The South Asian monsoon, also known as the Indian Summer Monsoon (ISM), brings approximately $70-80 \%$ of the annual rainfall of the region during the season June-September (JJAS) and is the major source for water needs of the densely populated country. Any changes in the South Asian monsoon rainfall (a component of the larger-scale Asian monsoon system) due to climate change will have serious impacts on the socio-economic conditions of the country. Understanding the monsoon hydroclimatic response to climate change is also of great scientific interest. Several recent studies have reported significant negative trends in the observed seasonal monsoon precipitation on regional and sub-regional scales over South
Asia since the 1950s (e.g. Guhathakurta and Rajeevan 2006; Chung and Ramanathan, 2006; Bollasina et al., 2011; Krishnan et al., 2013; Rajendran et al., 2012; Saha et al., 2014; Singh et al., 2014). Various studies have also noted a weakening trend of the large-scale summer monsoon circulation during recent decades (e.g. Tanaka et al., 2004; Abish et al., 2013; Fan et al., 2010; Krishnan et al., 2013). Few modelling studies have attributed the climate forcing by aerosols as the major driver for the decreasing precipitation trend over the Indian region (see Chung and Ramanathan, 2006; Bollasina et al., 2011). There is also a view that rapid increase of moisture in a global warming environment can increase the atmospheric stability and weaken the tropical and monsoon circulations (e.g. Kitoh et al., 1997; Douville et al., 2000; Veechi 
et al., 2006; Ueda et al., 2006). High-resolution model simulations reveal that a weakening of the south-westerly monsoon winds can in turn reduce orographic precipitation over the Western Ghat mountains (see Krishnan et al., 2013; Rajendran et al., 2012).

The satellite-derived soil moisture data from the Tropical Rainfall Measuring Mission (TRMM) during 1998-2008 indicate significant decreasing trends in soil moisture and evapotranspiration over many places globally and also over the Indian region (Jung et al., 2010). An increasing trend in the intensity and percent area affected by moderate droughts over India is noted by Kumar et al. (2013) during recent decades using a drought monitoring index viz., Standardized Precipitation Evapotranspiration Index (SPEI) which is based on climatic water balance. However, an understanding of whether these changes in soil moisture and evapotranspiration over India are responding to the anthropogenic forcing is lacking. This is in spite of the importance of these regional water balance components from scientific and societal perspectives, given their implications on climate, agriculture and other human activities (Seneviratne et al., 2006). One of the earliest investigations on the temporal and spatial variations of soil moisture response to global warming was conducted by Wetherald and Manabe (1999) using long-term integrations of a coupled atmosphere-ocean global circulation model. Their results suggested that soil dryness due to global warming was prominently detectable over the mid-continental regions of middle and high latitudes by the first half of the 21st century. Over the Indian subcontinent, they noted an increase of soil moisture during the summer season due to increase of precipitation. However, these results were based on coarse resolution model simulations. Furthermore, models tend to exaggerate summer drying through overestimation of evaporation particularly in regions where soil moisture and energy are not limited (Seneviratne et al., 2002). Proper understanding of land-surface response over the Indian region to climate change is lacking due to poor simulation of regional water balance in many coupled model intercomparison project (CMIP) models (Hasson et al., 2013). For example, Jourdain et al. (2013) reported a large spread in the simulated seasonal mean Indian Summer Monsoon rainfall as well as the seasonality of rainfall among the state-of-the-art CMIP5 coupled models used for the fifth Assessment Report of the Intergovernmental panel on Climate Change (IPCC). Also a majority of CMIP models do not adequately capture the historical trend of decreasing precipitation over Indian monsoon region (e.g. Saha et al., 2014), with large uncertainties in future projections in the magnitude of monsoon precipitation over the region (Chaturvedi et al., 2012).

In this study, we have used a variable resolution global climate model from Laboratoire de Meterologie Dynamique (LMD), France with high-resolution (grid size $<35 \mathrm{~km}$ ) telescopic zooming over South Asia and coupled to a state-ofthe-art land-surface model, to better understand the regional land surface hydrological response to monsoonal changes.
The model simulations also account for transient changes in land-use and land-cover, which are prescribed from standard data sets used in the CMIP5 experiments (see next section). Sabin et al. (2013) have assessed the South Asian monsoon simulations from the telescopically zoomed LMD model. They noted that the high-resolution LMD simulations provide important value additions in representing moist convective processes and organized convective activity over the monsoon region; and also realistically captured the regional details of precipitation characteristics and their links to monsoonal circulation. This paper is organised as follows. Section 2 provides a description of the model, design of experiments and observed data used for this work. Results from the historical simulations and comparison with observations are discussed in Sect. 3. The results of land hydrological response are presented in Sect. 4. The detectable future changes in land hydrology are described in Sect. 5 and the conclusions are summarized in Sect. 6 .

\section{Model, data and methods}

\subsection{Model and experiments}

The climate model used in this study is the LMD global atmospheric general circulation model (AGCM) with enhanced resolution capability over a particular region of interest (see Hourdin et al., 2006; Sabin et al., 2013). The high-resolution zoom used in the LMDZ (where $\mathrm{Z}$ stands for zoom) model is centred at $15^{\circ} \mathrm{N}, 80^{\circ} \mathrm{E}$. The zoom domain $\left(15^{\circ} \mathrm{S}-40^{\circ} \mathrm{N}, 30-120^{\circ} \mathrm{E}\right)$ covers the entire South Asian monsoon region and the tropical Indian Ocean. The resolution is about $35 \mathrm{~km}$ in the zoom domain, and it becomes gradually coarser outside. Sabin et al. (2013) have evaluated different aspects of the South Asian monsoon simulation from this high-resolution model with telescopic zooming. The detailed description of the representation of physical processes in the version used here is given in Hourdin et al. (2006 and the references therein).

The LMDZ AGCM and the state-of-the-art land surface model Organizing Carbon and Hydrology in Dynamic Ecosystems (ORCHIDEE; Krinner et al., 2005) are fully coupled with two-way interactions between atmosphere and land surface. The ORCHIDEE includes the Schématisation des Echanges Hydriques à L'Interface Biosphère-Atmosphère surface-vegetation-atmosphere transfer scheme (SECHIBA; Ducoudré et al., 1993; de Rosnay and Polcher, 1998) and the Saclay Toulouse Orsay Model for the Analysis of Terrestrial Ecosystems carbon module (STOMATE). SECHIBA calculates the exchange of energy and water between the atmosphere and the biosphere along with the soil water budget. STOMATE simulates the phenology and carbon dynamics of the terrestrial biosphere such as photosynthesis, carbon allocation, litter decomposition, soil carbon dynamics, respiration etc., ORCHIDEE builds on the concept of plant functional types (PFT) to describe vegetation distributions. 
The land surface is represented as a heterogeneous mosaic of 12 PFTs and bare soil. The PFTs are defined based on ecological parameters such as plant structure (tree or grass), leaves (needleleaf or broadleaf), phenology (evergreen, summergreen or raingreen) and according to the type of photosynthesis for crops and grasses (C3 or C4).

We have conducted long-term simulation experiments using this configuration of the LMDZ GCM, with highresolution $(\sim 35 \mathrm{~km})$ zooming over South Asia. The first model simulation is the Historical run (HIST; 1886-2005), which uses both natural (e.g. volcanoes and solar variability) and anthropogenic forcing (e.g. green house gases (GHG), aerosols evolution estimated from transport models, land use and land cover changes etc.). The second experiment is Historical Natural run (NAT; 1886-2005), which uses only natural (e.g. volcanoes and solar variability) forcing. Another simulation, which is intended to understand likely future changes (2006-2095), uses both natural and anthropogenic forcing based on IPCC approved medium stabilization scenario Representative Concentration Pathway 4.5 (RCP 4.5), in which the net radiative forcing at the end of 2100 is $4.5 \mathrm{Wm}^{-2}$. Owing to the high computational costs of the high-resolution zoomed simulations, the model experiments in this study are based on a single realization.

The monthly bias adjusted sea surface temperature (SST) and sea-ice from the CMIP5 experiments with the coarser resolution atmosphere-ocean coupled GCM run from Institut Pierre Simon Laplace (IPSL-CM5A-LR; referred as IPSL hereafter) are used as boundary forcing for LMDZ experiments. Bias adjustment refers to the removal of model errors in present-day mean climate. The SST anomalies for HIST, NAT and RCP4.5 experiments of IPSL are superposed on the observed climatological mean SST from the AMIP (Atmospheric Model Intercomparison Project) data set (http://www-pcmdi.llnl.gov/projects/ amip/AMIP2EXPDSN/BCS/amip2bcs.php). This methodology assumes the statistical stationarity hypothesis, i.e., relationships inferred from historical data remain valid under a changing climate (Maraun 2012). The same procedure is applied for specifying sea-ice boundary conditions.

The prescribed evolution of $\mathrm{CO}_{2}$ concentrations from 1886 to 2095 for the LMDZ experiments is taken from the CMIP5 recommended data set and is described in Dufresne et al. (2013). For the historical period 1886-2005, the $\mathrm{CO}_{2}$ concentration is derived from the Law Dome ice-core record, the Mauna Loa record and the National Oceanic and Atmospheric Administration (NOAA) global-mean record. From 2006 onwards in the RCP4.5 scenario, $\mathrm{CO}_{2}$ emissions and concentrations are projected by a reduced-complexity carbon cycle-climate model MAGICC6 (Meinshausen et al., 2011) such that the radiative forcing reaches $4.5 \mathrm{Wm}^{-2}$ at the end of 2100 and the $\mathrm{CO}_{2}$ concentration stabilizing at $543 \mathrm{ppmv}$ in 2150. The concentration of other GHGs like $\mathrm{CH}_{4}, \mathrm{~N}_{2} \mathrm{O}$, CFC-11 and CFC-12 are directly prescribed in the radiative code of the model based on the recommended CMIP5 data sets.

Time-varying distribution of aerosols and gaseous reactive species in the troposphere are specified in the LMDZ experiments based on the Interaction with Chemistry and Aerosol (INCA) model as part of the IPSL-CM5A-LR simulations (Dufresne et al., 2013). The methodology to build the aerosol field as well as its evolution and realism is described in more detail in Szopa et al. (2013).

The land use changes are prescribed using the historical crop and pasture data sets developed by Hurtt et al. (2011), which are also being used for the IPCC CMIP5 simulations. These data sets provide information on human activities (crop land and grazed pastureland) on a $0.5^{\circ} \times 0.5^{\circ}$ horizontal grid. The land-cover map used for both the historical and future period has been obtained starting from an observed present-day land-cover map (Loveland et al., 2000), which already includes both natural and anthropogenic vegetation types. These data sets are included in LMDZ following the methodology described by Dufresne et al. (2013).

\subsection{Data}

The model climate is compared with observational data to assess the model reliability. For this purpose we have used winds, precipitation and temperature data from observationbased and reanalysis estimates. The monthly circulation data at 850 and $200 \mathrm{hPa}$ are obtained from a recent reanalysis produced by the European Centre for Medium-Range Weather Forecasts (ECMWF) called ERA-Interim (ERAI; Dee and Uppala, 2009; Dee et al., 2011) for the time period 1979-2005. Monthly Surface air temperature over land at the $0.5^{\circ} \times 0.5^{\circ}$ resolution from Climatic Research Unit (CRU TS3.1; Harris et al., 2014) for the period 1951-2005 is used. Precipitation observations over land from the Asian Precipitation - Highly Resolved Observational Data Integration Towards Evaluation of Water Resources (APHRODITE) gridded $\left(0.5^{\circ} \times 0.5^{\circ}\right)$ daily rainfall data set (Yatagai et al., 2009) and from the India Meteorological Department (IMD) gridded $\left(0.25^{\circ} \times 0.25^{\circ}\right)$ daily rainfall data set (Pai et al., 2014) for the period 1951-2005 are used. In order to compare the model simulated precipitation over ocean regions, the observation-based monthly gridded $\left(2.5^{\circ} \times 2.5^{\circ}\right)$ precipitation data obtained from Climate Prediction Centre Merged Analysis of Precipitation (CMAP; Xie and Arkin, 1997) is also used. The model simulated monthly land surface hydrological components are compared with the corresponding multi-model mean computed from the multiple off-line land model simulations of Global Land Data Assimilation System (GLDAS; Rodell et al., 2004) available at $1^{\circ} \times 1^{\circ}$ resolution.

\subsection{Methodology}

The long-term mean summer monsoon climate simulated by the IPSL and LMDZ models are evaluated by comparing 

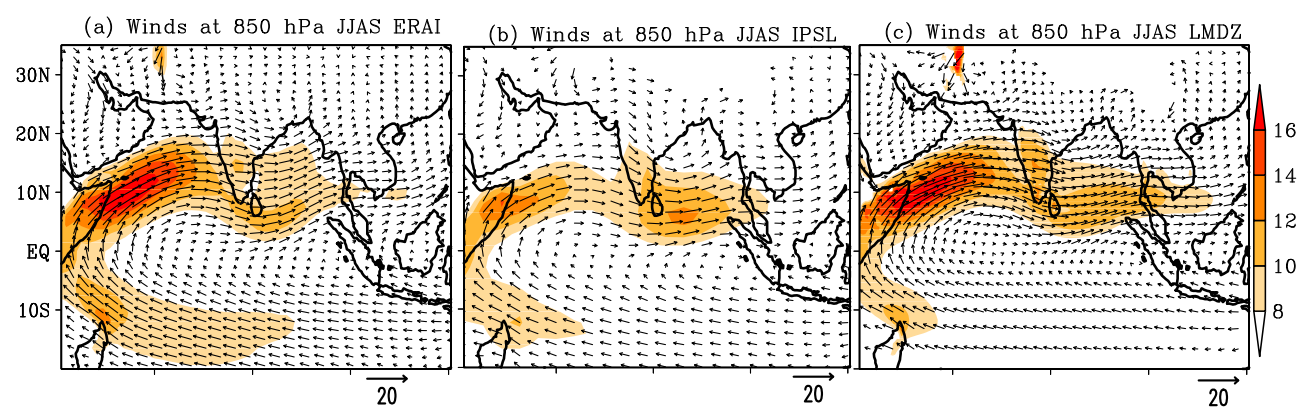

(d) Winds at $200 \mathrm{hPa}$ JJAS ERAI

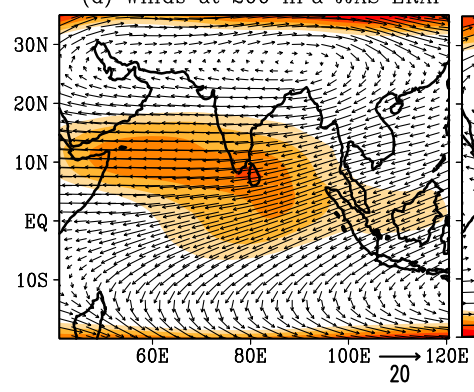

(e) Winds at $200 \mathrm{hPa}$ JJAS IPSL
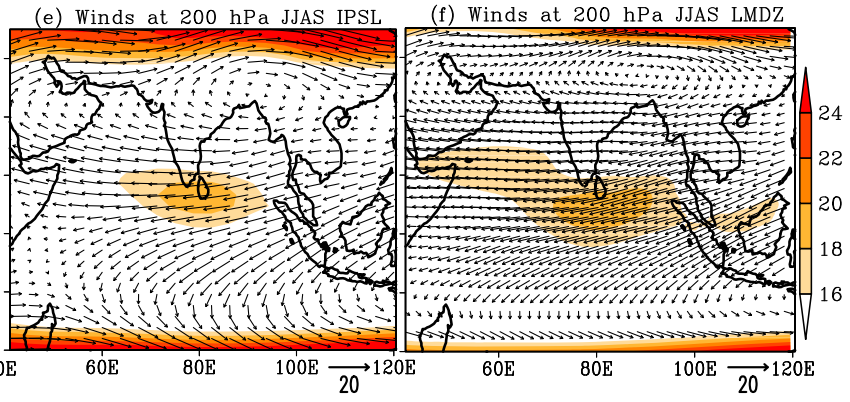

Figure 1. Spatial maps for JJAS mean wind fields ( $\mathrm{m} \mathrm{s}^{-1}$ ) at (top) $850 \mathrm{hPa}$ and (bottom) $200 \mathrm{hPa}$ for (a, d) ERAI (1979-2005), (b, e) IPSL (1951-2005) and (c, f) LMDZ (1951-2005) simulations. Shading denotes wind magnitude.

the spatial pattern of the wind circulation from their HIST simulations with the ERAI reanalysis. The spatial patterns of the simulated $2 \mathrm{~m}$ temperature, precipitation and evapotranspiration for these model runs are also compared with the observation-based gridded estimates. The pattern correlations for these model simulated fields are computed by regridding them on the corresponding reference data grid points to assess the ability of the IPSL and LMDZ models in capturing the large-scale features of mean climate. Furthermore, the annual water balance in land region over India simulated in both the models is compared with the GLDAS estimates. The spatial patterns of the linear trends simulated by the IPSL and LMDZ models over India during the summer monsoon season for temperature and precipitation are evaluated by comparing with the CRU and APHRODITE gridded observational estimates respectively. The statistical significance of trends are tested using the Student $t$ test. The LMDZ model simulated anthropogenic influence on the summer monsoon climate is assessed by comparing the areaaveraged linear trends of temperature and precipitation over Indian land region in the HIST with the NAT simulation of this model. The response of the land surface hydrology to anthropogenic forcing is brought out by computing the linear trends for total soil moisture and evapotranspiration for the historical as well as for a future climate change scenario. The detectability of soil moisture changes in response to the anthropogenic forcing is assessed following Wetherald and Manabe (1999), by comparing the magnitudes of soil moisture changes against the standard deviation of the natural soil moisture variability in the NAT integration. The soil moisture changes are computed with respect to the long-term mean of NAT integration, and the changes are considered to be detectable when they exceed standard deviation of the natural variability.

\section{Model simulation of mean climate}

\subsection{Mean summer monsoon features}

In this section, the simulations of the mean summer monsoon in the LMDZ model and the driving IPSL model are discussed and validated by comparison with reanalysis products and gridded observational estimates. Figure 1 shows the JJAS mean climatology of the lower $(850 \mathrm{hPa})$ and upper $(200 \mathrm{hPa})$ tropospheric wind circulation. The large-scale lowlevel circulation features, viz. the cross equatorial monsoon flow across the Indian Ocean, the Somali jet over the Arabian Sea and the monsoon trough over the Indian subcontinent can be noted in ERAI, the IPSL and LMDZ simulations (Fig. 1a-c). The wind climatology along the monsoon trough and head Bay of Bengal simulated by LMDZ is relatively closer to ERAI, as compared to the IPSL simulation. The pattern correlation between the simulated and observed lowlevel wind climatology over the domain $\left(20^{\circ} \mathrm{S}-35^{\circ} \mathrm{N}, 40\right.$ $120^{\circ} \mathrm{E}$ ) is 0.93 for LMDZ and 0.85 for the IPSL model. The major summer-time upper tropospheric wind circulation features such as the Tropical Easterly Jet over the Indian subcontinent, the Tibetan anticyclone and the subtropical westerly to the north of the subcontinent can be noted in ERAI and are captured in the IPSL and LMDZ simulations (Fig. 1d-f). 

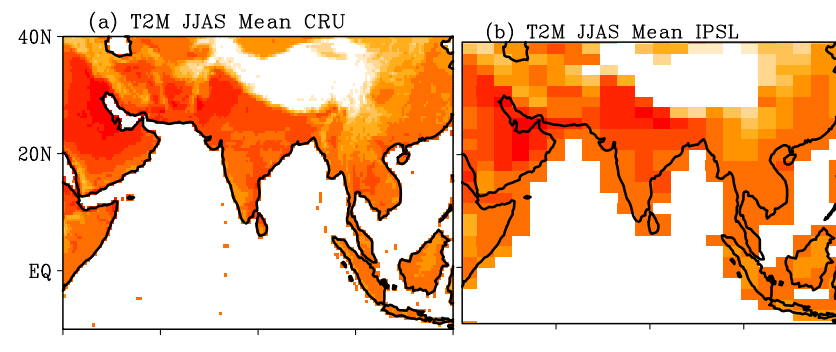

(c) T2M JJAS Mean LMDZ
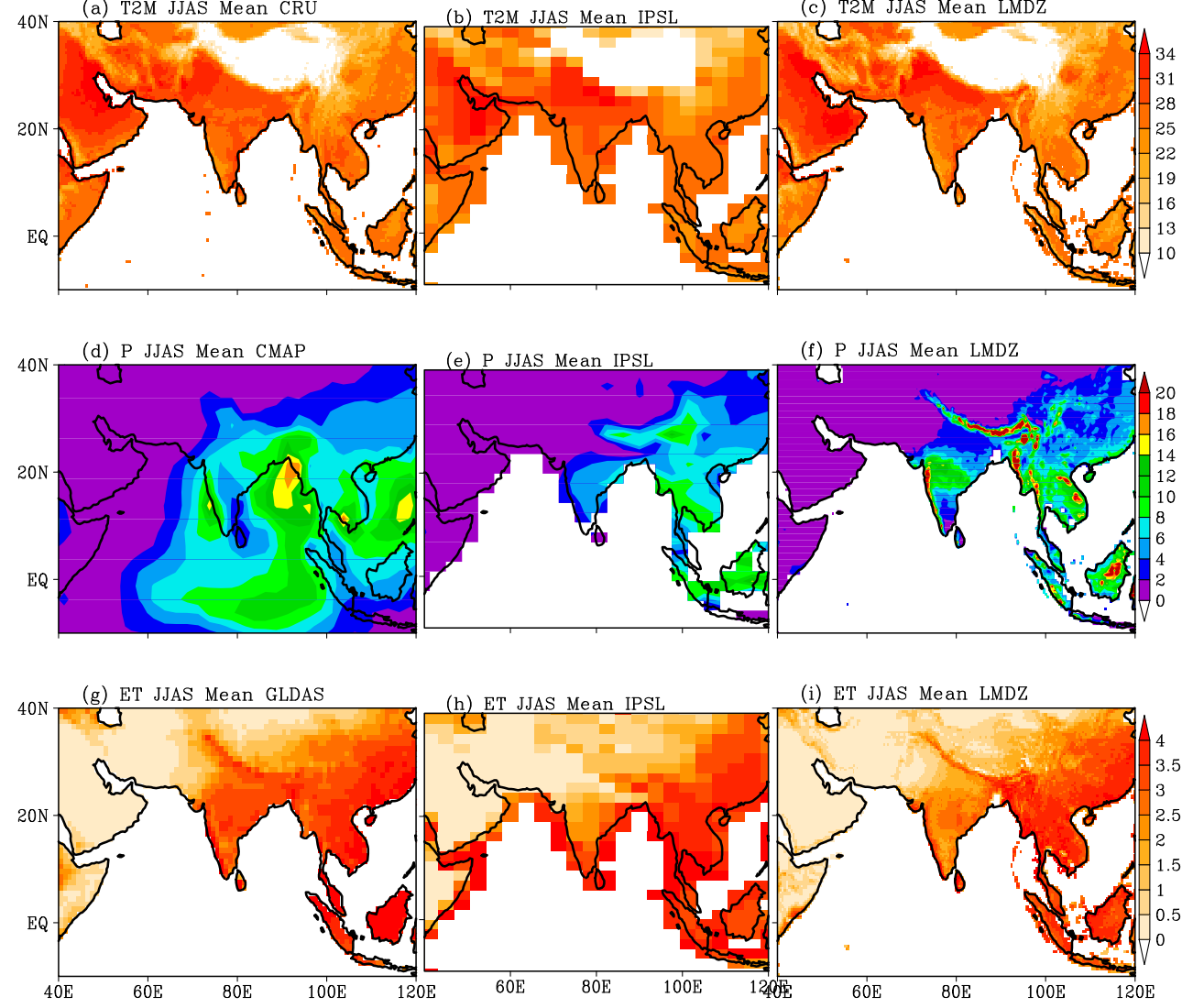

Figure 2. Spatial distributions of JJAS mean (top) $2 \mathrm{~m}$ air temperature $\left(\mathrm{T} 2 \mathrm{M} ;{ }^{\circ} \mathrm{C}\right)$, (middle) precipitation $\left(\mathrm{P}\right.$; mm $\left.\mathrm{d}^{-1}\right)$ and $($ bottom) evapotranspiration (ET; $\mathrm{mm} \mathrm{d}^{-1}$ ) from (a, d, g) observations or multi-model data, from HIST simulations of (b, e, h) IPSL and (c, f, i) LMDZ models. The period of analysis for CMAP and GLDAS is 1979-2005 and for CRU, model simulations the time period is 1951-2005.

Figure 2 shows the spatial distributions of JJAS mean climatology of $2 \mathrm{~m}$ air temperature, precipitation and evapotranspiration (ET). The region of high temperatures with east-west orientation over north-west India and Pakistan (Fig. 2a) coincides with the monsoon trough and is better captured in the high-resolution LMDZ simulation (Fig. 2c) as compared to the IPSL coarse resolution model (Fig. 2b). The near-surface air temperatures are underestimated both in LMDZ and IPSL simulations over central and peninsular India. The pattern correlations of the simulated and observed (CRU) mean surface air temperature over the land region $\left(70-90^{\circ} \mathrm{E}, 10-28^{\circ} \mathrm{N}\right)$ are found to be 0.95 and 0.81 for the LMDZ and IPSL models respectively.

We also compared the simulated mean precipitation from the LMDZ and IPSL models with the CMAP and APHRODITE precipitation data sets over the Indian monsoon region. The CMAP is a merged precipitation gridded product obtained by combining satellite and rain gauge observations and is available both over land and oceanic regions on a $2.5^{\circ} \times 2.5^{\circ}$ grid (Xie and Arkin, 1997). The APHRODITE is a high-resolution $0.5^{\circ} \times 0.5^{\circ}$ gridded rainfall data set constructed from rain gauge observations (Yata- gai et al., 2012). The summer monsoon precipitation over central India and along the Indo-Gangetic plains seen in the long-term observed climatology from CMAP (Fig. 2d) are simulated relatively better in the LMDZ (Fig. 2f) model than the driving IPSL model (Fig. 2e), even though their magnitudes over these parts of India are less than the observed estimate. It is noted that LMDZ model is able to capture the rainfall peak over the Bay of Bengal (Fig. S1 in the Supplement) and the area averaged rainfall over the region 80 $98^{\circ} \mathrm{E} ; 8-22^{\circ} \mathrm{N}$ covering Bay of Bengal is found to be 10.54 and $8.48 \mathrm{~mm} \mathrm{~d}^{-1}$ for CMAP and LMDZ respectively. It is also found that the high-resolution LMDZ model simulated rainfall maxima along the west coast, foot hills of Himalayas and north-east India are closer to high-resolution rain-gauge based observed climatology from APHRODITE (see the Supplement Fig. S2a in the Supplement). The pattern correlations of the simulated and observed (APHRODITE) mean precipitation over the Indian land region $\left(70-90^{\circ} \mathrm{E}, 10\right.$ $28^{\circ} \mathrm{N}$ ) are found to be 0.47 and 0.20 for the LMDZ and IPSL models respectively. Previous studies have shown that there is considerable spread among the different observed precipitation data sets over India (Collins et al., 2013; Kim et al., 

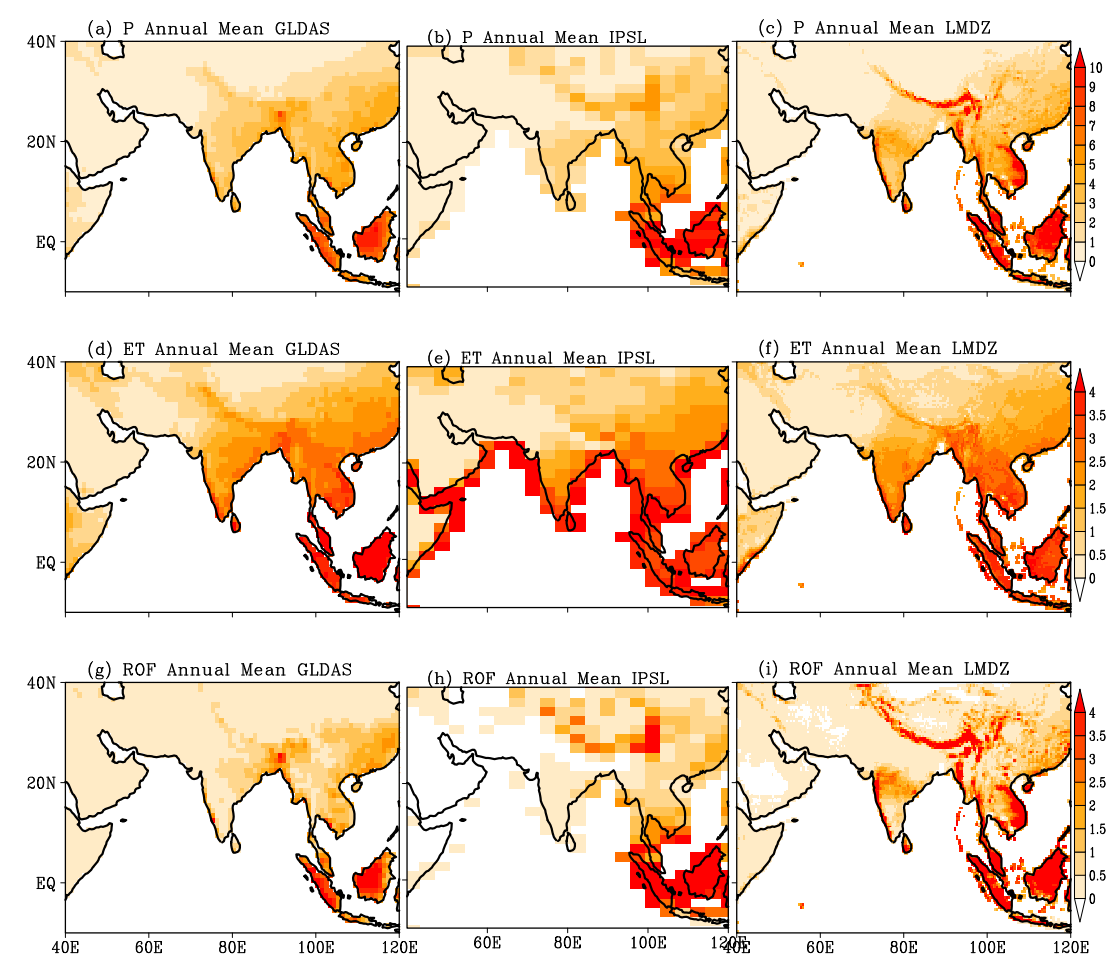

Figure 3. Spatial maps for annual mean (top) precipitation, (middle) evapotranspiration and (bottom) runoff from (a, d, g) GLDAS, (b, e, h) IPSL and (c, f, i) LMDZ simulations during 1979-2005. Units are $\mathrm{mm} \mathrm{d}^{-1}$.
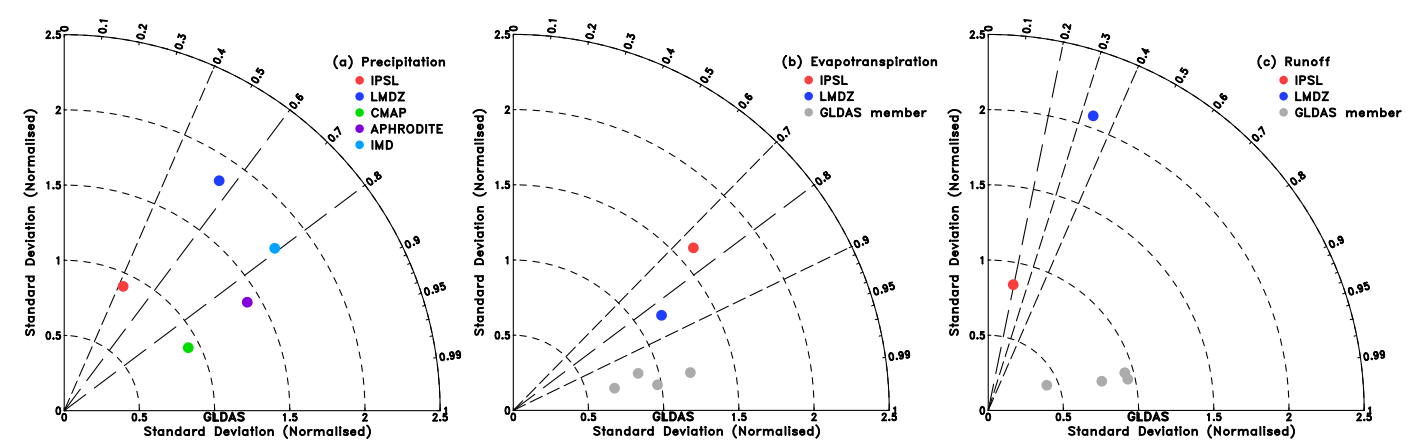

Figure 4. Taylor diagram for the annual-mean (a) precipitation, (b) evapotranspiration and (c) total runoff climatology (1979-2005) from the IPSL and LMDZ model simulations averaged over land grid points in India $\left(70-90^{\circ} \mathrm{E} ; 10-28^{\circ} \mathrm{N}\right)$. The radial coordinate shows the standard deviation of the spatial pattern, normalized by the observed standard deviation. The azimuthal variable shows the correlation of the modelled spatial pattern with the observed spatial pattern. The distance between the reference data set (GLDAS) and individual points corresponds to root mean square error (RMSE).

2015). Our analysis using the $0.25^{\circ} \times 0.25^{\circ}$ high-resolution rainfall data set from IMD (Pai et al., 2014; Fig. S2b in the Supplement) shows that the area-averaged summer monsoon rainfall over India is comparable with the APHRODITE (Fig. S3 in the Supplement).

The simulated evapotranspiration (ET), which is a major component of hydrological cycle, is compared with the GLDAS gridded data set (Rodell et al., 2004). Observational uncertainties of surface hydrologic variables are large (Bindoff et al., 2013). The GLDAS data set integrates observation- based data to drive multiple off-line land surface models to generate flux parameters and land surface state (e.g. soil moisture, evapotranspiration, runoff, sensible heat flux, etc). Since the GLDAS off-line land surface models are driven by observations and bias-corrected reanalysis fields, the multimodel estimates from GLDAS serve as physically consistent reference data sets for model validation of land surface fluxes and state (Seneviratne et al., 2010). The JJAS mean evapotranspiration from GLDAS, the IPSL and LMDZ model simulations are shown in Fig. $2 \mathrm{~g}-\mathrm{i}$. Note that the spatial distri- 
bution of the JJAS mean evapotranspiration from GLDAS (Fig. 2g) has a resemblance with the pattern of observed monsoon precipitation (Fig. 2d). The regions of high evapotranspiration over central, west coast of India and along the foot hills of the Himalayas are better simulated in the highresolution LMDZ as compared to the IPSL model (Fig. 2hi). It is noted that the pattern correlations of ET between the simulated and GLDAS data set over the Indian land region $\left(70-90^{\circ} \mathrm{E}, 10-28^{\circ} \mathrm{N}\right)$ is 0.81 for LMDZ and 0.58 for the coarse resolution IPSL model. The better ET distribution in the high resolution LMDZ simulation, as compared to the IPSL coarse resolution model, is consistent with simulated precipitation in the two models. Note that the orographic precipitation along the west coast of India and foot hills of Himalayas are better captured in LMDZ, whereas the IPSL model significantly underestimates rainfall over the Indian region resulting in low ET.

Here, we examine the annual water balance components at the surface in terms of precipitation, evapotranspiration and runoff from the LMDZ and IPSL simulations and compare with the GLDAS data set (Fig. 3). The Taylor diagram (Fig. 4; Taylor 2001) shows the skill of the models in simulating the annual spatial climatology and variability of precipitation, ET and runoff over the Indian land region with GLDAS as the reference data set. The LMDZ model simulates the spatial pattern of precipitation relatively better than the IPSL model when compared to the GLDAS forcing (Fig. 4a). Although the LMDZ model overestimates the spatial variability in comparison with the coarser resolution GLDAS precipitation forcing and the CMAP observations, the magnitude is comparable with the high-resolution gridded observational data sets (IMD and APHRODITE). The LMDZ model simulated spatial pattern and variability of evapotranspiration are closer to the estimates from the GLDAS multi-model mean as well as to each member models than that for the IPSL model (Fig. 4b). The total runoff simulated by the LMDZ model shows a relatively better spatial pattern than the IPSL model in comparison with the GLDAS estimates (Fig. 4c). However this high-resolution model overestimates the spatial variability relative to the coarser resolution GLDAS estimates. Additionally, it is important to ensure model simulations properly capture surface water balance on regional scales. Hasson et al. (2013) noted that biases in simulating annual surface water balance on regional scales often introduce considerable uncertainty in assessment of surface hydrological response to climate change. Keeping this in view, we examined the difference of annual precipitation minus evapotranspiration (P-ET) and the annual runoff averaged over the Indian land region $\left(70.0-90.0^{\circ} \mathrm{E}\right.$; $10.0-28.0^{\circ} \mathrm{N}$ ) from the GLDAS data set and the two model simulations. The area-averaged values are shown in Table 1. It can be noticed that the annual (P-ET) and runoff in GLDAS are in close balance (Table 1). A reasonably good balance between (P-ET) and runoff can also be noted in the LMDZ simulation, whereas the annual runoff in the IPSL model far
Table 1. Long-term annual means in $\mathrm{mm} \mathrm{d}^{-1}$ for precipitation (P), Evapotranspiration (ET), runoff (R) and P-ET from GLDAS, IPSL and LMDZ models during 1979-2005 averaged over the domain 70$90^{\circ} \mathrm{E} ; 10-28^{\circ} \mathrm{N}$. The water balance is highlighted in bold.

\begin{tabular}{lrrr}
\hline & GLDAS & IPSL & LMDZ \\
\hline P & 2.63 & 1.81 & 2.97 \\
ET & 1.99 & 2.25 & 1.92 \\
R & $\mathbf{0 . 6 5}$ & $\mathbf{0 . 2 8}$ & $\mathbf{1 . 0 6}$ \\
P-ET & $\mathbf{0 . 6 4}$ & $-\mathbf{0 . 4 4}$ & $\mathbf{1 . 0 5}$ \\
\hline
\end{tabular}

exceeds the (P-ET). The fairly consistent balance between the annual (P-ET) and runoff in the LMDZ model averaged over the Indian region provides confidence in interpreting the land surface hydrological variations as compared to the IPSL coarse resolution model.

\subsection{Simulation of climate trends over the monsoon region}

A climate model's credibility is increased if the model is able to simulate past variations in climate such as the trends over the twentieth century, when given realistic forcings (Flato et al., 2013). The long-term drying trends (significant at $>95 \%$ level) in the summer monsoon precipitation over parts of central India, along the Indo-Gangetic plains and the narrow western ghat region during the past half century from APHRODITE (Fig. 5a) are captured with higher magnitudes in the HIST simulation of LMDZ (Fig. 5c) model. While the driving IPSL model (Fig. 5b) shows significant increasing trends in precipitation over most parts of India. The observed (CRU) significant warming trends over most parts of India (Fig. 6a) are captured by both simulations, with a relatively larger magnitude in LMDZ (Fig. 6c) than IPSL (Fig. 6b) model. Further detailed analysis based on the LMDZ model experiment with only natural forcing (NAT) brings out the role of anthropogenic forcing on these drying and warming trends over India. The observed (APHRODITE) rainfall shows a significant drying trend $\left(-0.33 \mathrm{~mm} \mathrm{~d}^{-1}(55 \mathrm{yr})^{-1}\right)$ in summer monsoon precipitation over the Indian land region during 1951-2005 and the HIST simulations also shows a statistically significant trend of $\left.-0.8 \mathrm{~mm} \mathrm{~d}^{-1}(55 \mathrm{yr})^{-1}\right)$ (Fig. S4b in the Supplement). The observed (CRU) seasonal warming trend for the same period $\left(0.5^{\circ} \mathrm{C}(55 \mathrm{yr})^{-1}\right)$ is significant over Indian land region and the HIST simulation of LMDZ model also captured a significant warming trend of $1.1^{\circ} \mathrm{C}(55 \mathrm{yr})^{-1}$ (Fig. S4a in the Supplement). The surface air temperature and precipitation trends simulated in response to natural forcings only (NAT) are generally close to zero, and are inconsistent with observed trends over Indian land region. These findings are further supported by the simulated weaker summer monsoon circulation and reduced precipitation over Indian subcontinent in the HIST experiment of 
(a) P JJAS trend APHRODITE

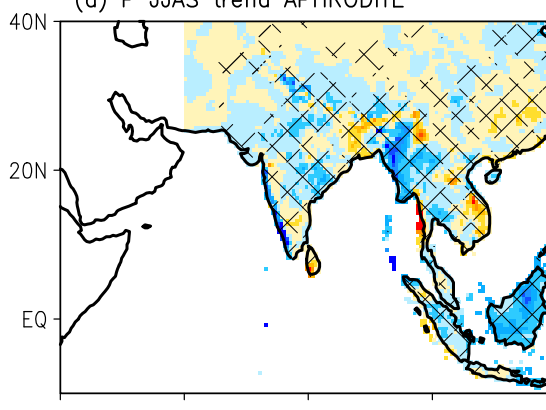

(b) P JJAS trend IPSL

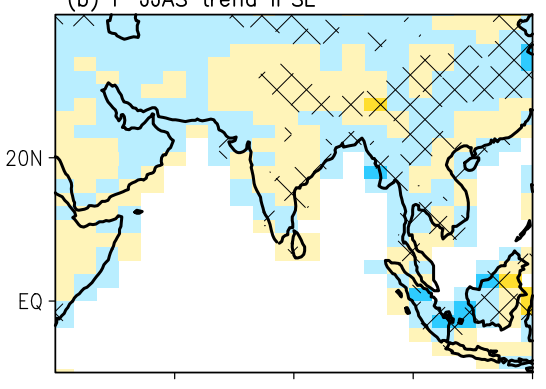

(c) P JJAS trend LMDZ

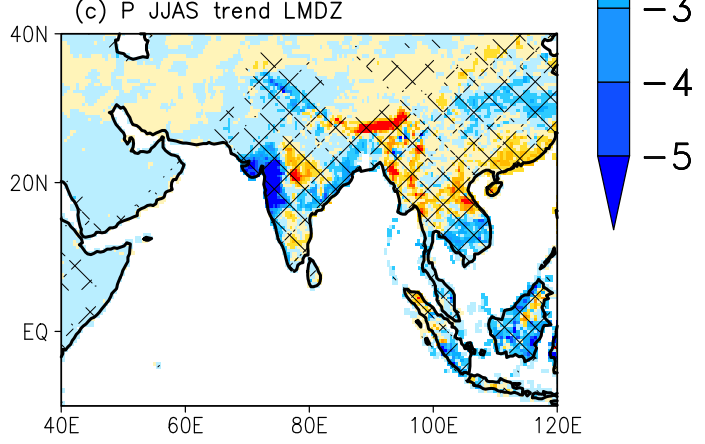

Figure 5. Spatial maps of linear trends in JJAS rainfall based on (a) APHRODITE, (b) IPSL and (c) LMDZ HIST simulation. Units are $\mathrm{mm} \mathrm{d}^{-1}$ change over the period 1951-2005. Trend values exceeding the $95 \%$ level of statistical significance based on Student's $t$ test are hatched.

LMDZ model compared to the NAT experiment (Fig. S5 in the Supplement). The finding that the observed changes are consistent with the LMDZ simulation that includes human influence (HIST), and are inconsistent with that which does not (NAT), would be sufficient for attribution studies as they typically assume that models simulate the large-scale spatial and temporal patterns of the response to external forcing correctly, but do not assume that models simulate the magnitude of the response correctly (Bindoff et al., 2013). Hence this high-resolution HIST simulation of LMDZ atmospheric model will be an important value addition for understanding the regional land surface hydrological responses that may be influenced by the anthropogenic forced changes in summer monsoon over the Indian subcontinent. (a) T2M JJAS trend CRU

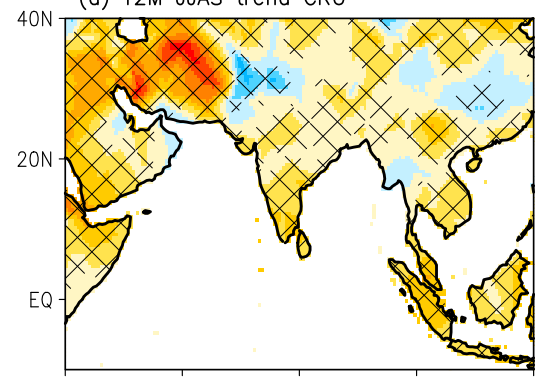

3

2.5

2

(b) T2M JJAS trend IPSL

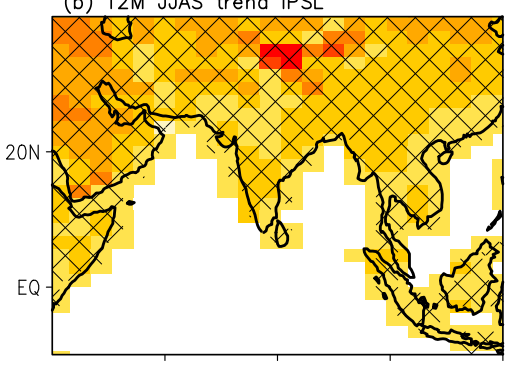

1.5

(c) T2M JJAS trend LMDZ

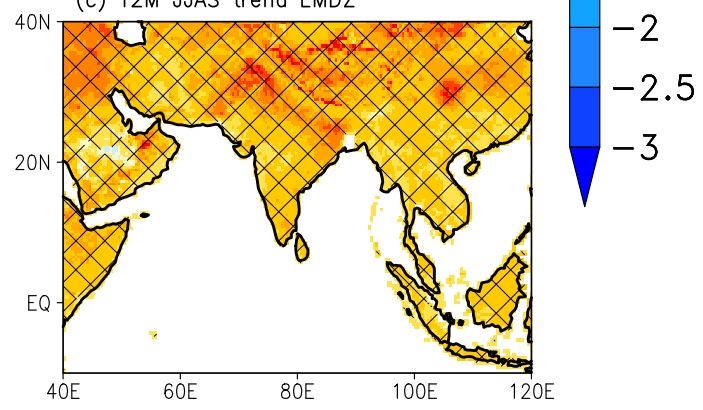

Figure 6. Spatial maps of linear trends in $2 \mathrm{~m}$ air temperature for JJAS season based on (a) CRU, (b) IPSL and (c) LMDZ HIST simulation. Units are ${ }^{\circ} \mathrm{C}$ change over the period 1951-2005. Trend values exceeding the $95 \%$ level of statistical significance based on Student's $t$ test are hatched.

\section{Response of land surface hydrology to the changing monsoon}

We further assess the long-term changes in the surface hydrologic variables such as soil moisture (SM) and ET in the HIST simulation of LMDZ. In association with the reduction of summer monsoon precipitation, the HIST simulation of LMDZ model also indicates significant soil moisture (SM) drying trends over most parts of India (Fig. 7a). This accounts to about $14 \mathrm{~mm}(55 \mathrm{yr})^{-1}$ reduction in soil moisture $(5 \%)$ when area-averaged over the Indian land region. The comparison of the seasonal trends at each grid point over the Indian land region indicates a dominant control of precipitation on SM (Fig. S6 in the Supplement). The SM is a source of water for the atmosphere through processes leading to ET from land, which include mainly plant transpiration and bare soil evaporation. The HIST simulation of LMDZ 
(a) TSM JJAS trend HIST

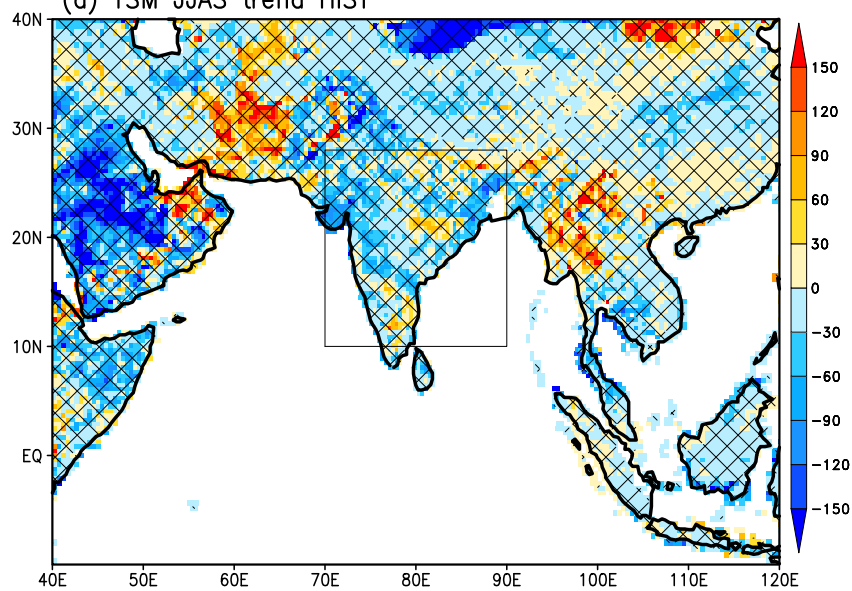

(b) ET JJAS trend HIST

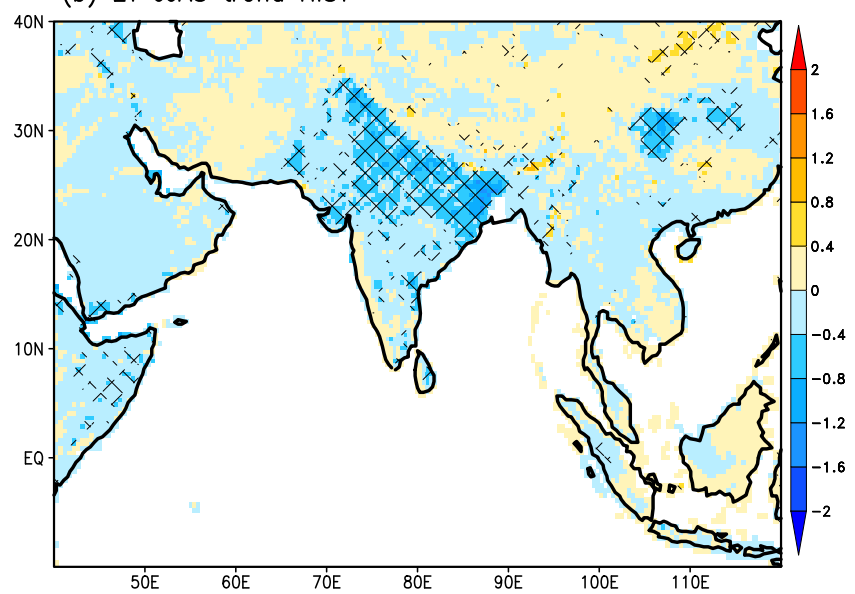

Figure 7. Spatial distribution of linear trends in JJAS mean (a) total soil moisture (SM) and evapotranspiration (ET) from HIST simulation of LMDZ. Units are $\mathrm{mm}$ and $\mathrm{mm} \mathrm{d}^{-1}$ change over the period 1951-2005 for SM and ET respectively. Trend values exceeding the $95 \%$ level of statistical significance based on Student's $t$ test are hatched.

model shows a significant decrease of summer season mean ET over most parts of the Indian land region (Fig. 7b). The Indian land region area-averaged reduction in ET accounts for about $0.23 \mathrm{~mm} \mathrm{~d}^{-1}(55 \mathrm{yr})^{-1}(9.5 \%)$. The simulated regions of ET reduction mostly coincide with that of drier soil moisture.

The global hydrological cycle is generally expected to intensify in a warming world, leading to an increase in ET (Huntington, 2006). On the other hand, station observations of pan evaporation over India indicate a significant decreasing trend in recent decades (Padmakumari et al., 2013). Long-term trends in ET are basically driven by limiting factors such as soil moisture or radiation both on regional (Teuling et al., 2009) and global (Jung et al., 2010) scales. A comparison of the simulated seasonal ET trends at each grid point over the Indian land region with the corresponding SM trends shows significant correlation between ET reduction and SM
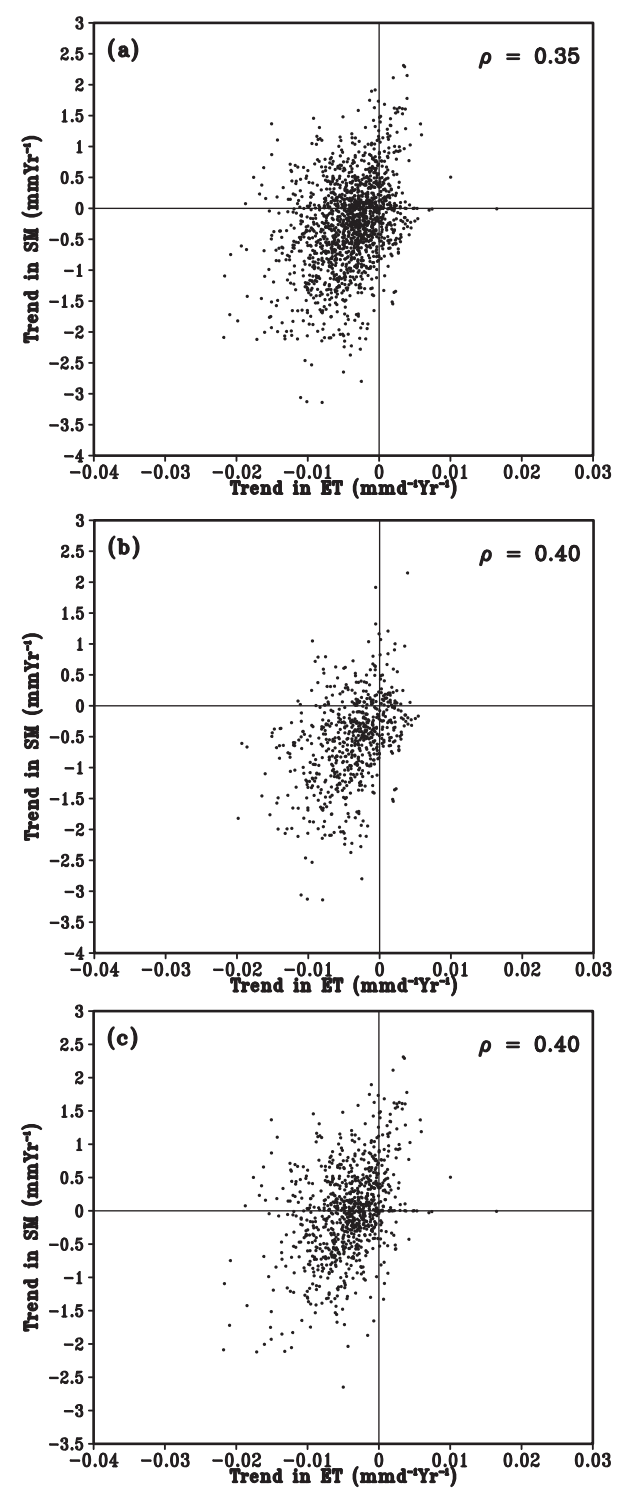

Figure 8. (a) Scatter plot of linear trends in JJAS mean evapotranspiration (ET) during the 55-year (1951-2005) period as a function of the linear trends of total soil moisture (SM) for all the grid points over the region $70-90^{\circ} \mathrm{E} ; 10-28^{\circ} \mathrm{N}$. (b and c) same as (a) expect for the grid points with trends in surface downward short wave radiation (b) increasing and (c) decreasing.

drying (Fig. 8a). This relationship is also noticed under conditions of increasing and decreasing surface incident solar radiation trends (Fig. $8 \mathrm{~b}-\mathrm{c}$ ), implying that SM drying plays a dominant role in ET reduction over the Indian monsoon region, with minor contributions from changes in solar radiation reaching at surface. In fact, it can be noticed from Fig. 8b that decrease of ET is mostly accompanied by decrease of SM over a majority of grid-points over the Indian region, whereas increases in ET and global radiation are seen over fewer grid points. The above analysis suggests that the 
(a) T2M JJAS trend LMDZ
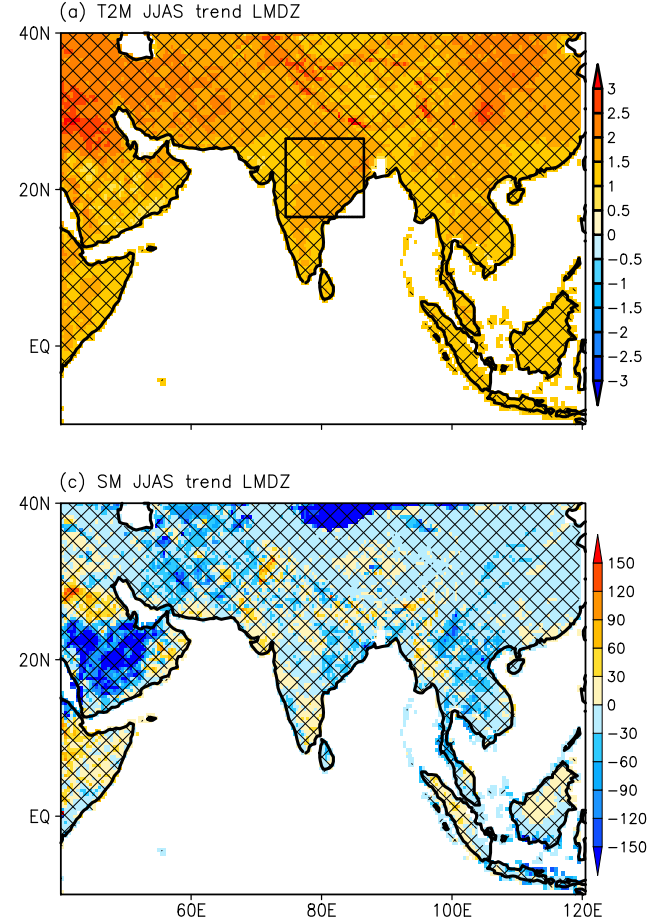

(b) PR JJAS trend LMDZ
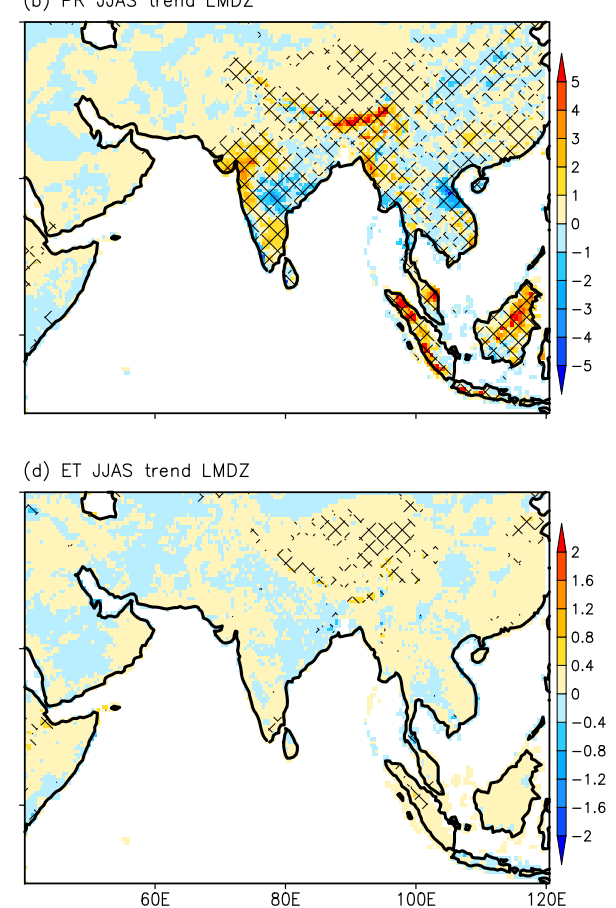

Figure 9. Spatial distribution of linear trends in (a) $2 \mathrm{~m}$ air temperature $\left({ }^{\circ} \mathrm{C}\right)$, (b) precipitation $\left(\mathrm{mm} \mathrm{d}^{-1}\right)$, (c) soil moisture $(\mathrm{mm})$ and (d) evapotranspiration $\left(\mathrm{mm} \mathrm{d}^{-1}\right)$ from RCP simulation of LMDZ. Trends are expressed as change over the period 2006-2095. Trend values exceeding the $95 \%$ level of statistical significance based on Students $t$ test are hatched. The box indicates central India $\left(74.5-86.5^{\circ} \mathrm{E}\right.$; $16.5-26.5^{\circ} \mathrm{N}$ ) region.

SM drying trends, caused by local precipitation variations, largely drive ET reduction over the region.

\section{Future changes in surface hydrology}

The spatial distributions of the projected future trends in temperature, precipitation, soil moisture and evapotranspiration for the period 2006-2095 under RCP 4.5 scenario are shown in Fig. 9. The significant increase of temperature over the entire Indian land region is consistent with the increasing radiative effects of the rising $\mathrm{CO}_{2}$ concentration in the future (Fig. 9a). The magnitude of this warming is larger (1.5$2{ }^{\circ} \mathrm{C}$ ) at northern regions including the Indo-Gangetic planes and smaller along the western regions and the southernmost parts of India. The projected future trends in precipitation show regions of significant increase over western and southeastern parts and decrease over central India (Fig. 9b). Note that the spatial pattern of trends in SM mostly follows the pattern of precipitation trends and is dominated by drying of SM (Fig. 9c). It is also interesting to note that the spatial pattern of projected trends in ET resembles the pattern of trends in SM (Fig. 9d).

The detectability of soil moisture changes to anthropogenic forcing is computed following the approach of Wetherald and Manabe (1999). The magnitudes of soil moisture changes with respect to the long-term mean (1886-2005) of NAT integration are compared against the standard deviation of the natural soil moisture variability in the NAT integration. The changes are considered to be detectable when they exceed the standard deviation of the natural variability. For this analysis, we sequentially arrange variables for the HIST time period (1886-2005) and RCP4.5 scenario (20062095) as a continuous time series, which will be henceforth referred to as ALL. Figure 10a shows the smoothed time series of 20-year running-mean values of summer-monsoon soil moisture anomalies during 1886-2095 based on the high-resolution (LMDZ) and coarse-resolution (IPSL) simulations over the central Indian region $\left(74.5-86.5^{\circ} \mathrm{E}\right.$; $16.5-$ $26.5^{\circ} \mathrm{N}$; see box in Fig. 9a). The standard deviation of soil moisture in Fig. 10a is calculated from the corresponding natural (NAT) integrations. The appearance of a detectable change of soil moisture (exceeding 1 standard deviation of NAT) can be noted in the LMDZ simulation as early as 2010 and then the change is not prominent until the 2050s and thereafter remains detectable till the end of 21 st century. From Fig. 10, one can note coherent evolution of the soil moisture and precipitation variations. In addition, we also see more persistence in detectability of soil moisture as compared to that of precipitation. This is consistent with the result that the soil moisture spectra is dominated by lower frequency variations as opposed to the precipitation spectra (see Delworth and Manabe, 1988). We also verified that 
(a) $S M$

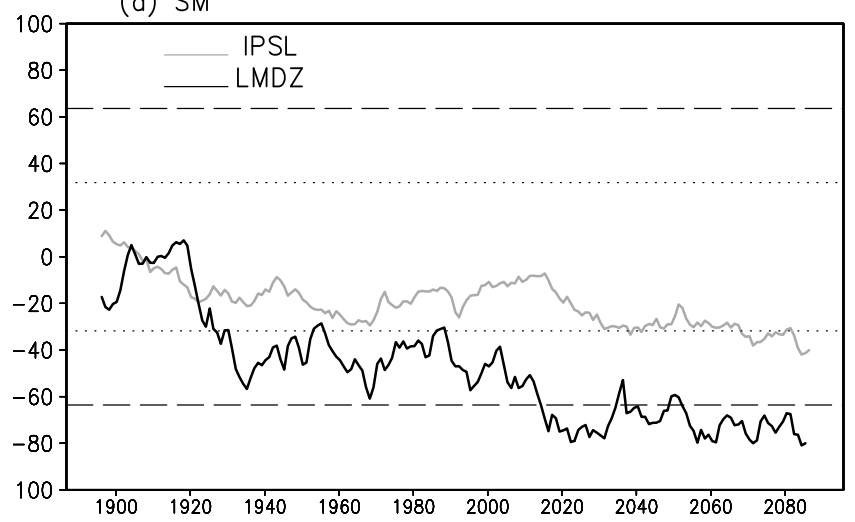

(b) $T 2 \mathrm{M}$

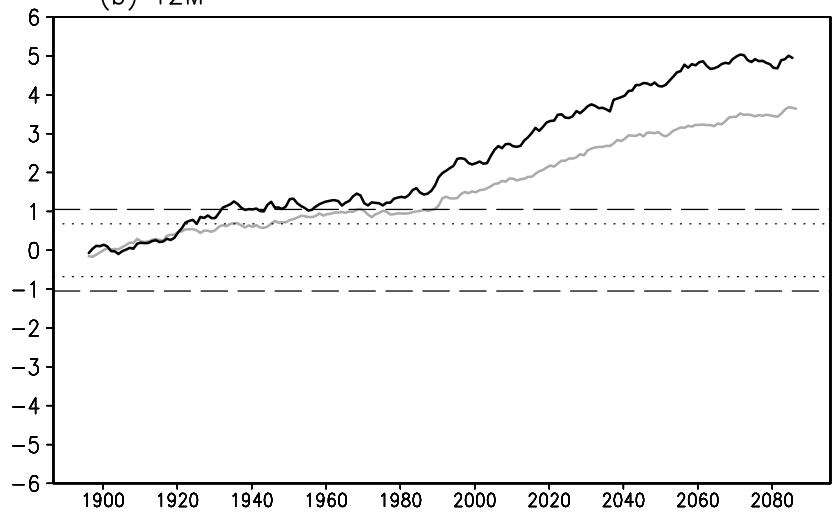

(c) $\mathrm{P}$

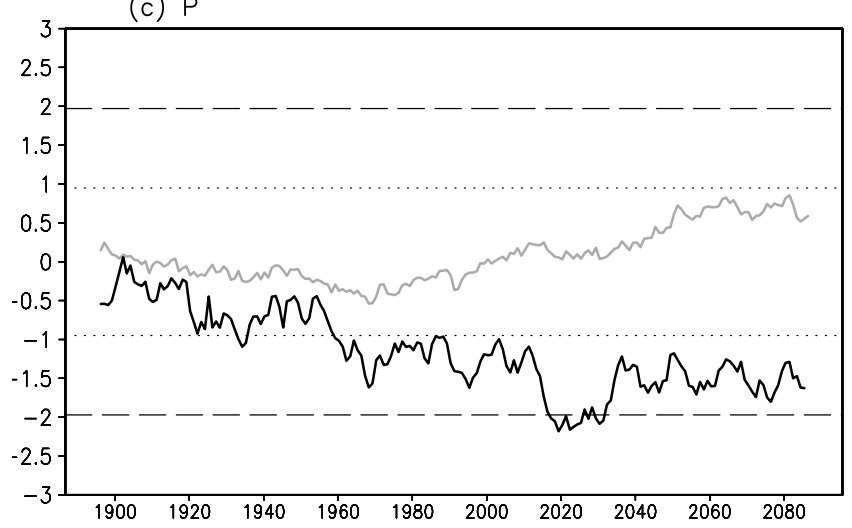

Figure 10. Time series of area-averaged anomalies of (a) soil moisture $(\mathrm{SM} ; \mathrm{mm})$, (b) $2 \mathrm{~m}$ air temperature $\left(\mathrm{T} 2 \mathrm{M} ;{ }^{\circ} \mathrm{C}\right)$ and (c) precipitation (P; $\left.\mathrm{mm} \mathrm{d}^{-1}\right)$ from ALL (HIST and RCP) experiments of (grey) IPSL and (black) LMDZ for the region 74.5-86.5 $\mathrm{E}$; $16.5-$ $26.5^{\circ} \mathrm{N}$. The yearly JJAS anomalies are computed as the difference from the corresponding long-term mean (1886-2005) of NAT integration. Each time series has been smoothed by a 20 -year running mean. The two horizontal dashed lines denote 1 standard deviation limits from the NAT integration computed from the yearly JJAS averages for LMDZ and dotted lines correspond to IPSL. there is no drift in soil moisture in the NAT integration of LMDZ model (figure not shown), which suggests that the decreasing trend of soil moisture in the HIST experiment is related to anthropogenic forcing. On the other hand, the SM variations in the IPSL simulation show decadal-scale variations with a slight decrease during latter part of the 21st century. Here, it is important to note that the surface warming trend between 1886 and 2005 is clearly borne out in both the IPSL and LMDZ models (Fig. 10b), with the magnitude of warming trend being more pronounced in the LMDZ simulation $\left(0.21 \mathrm{~K} \mathrm{decade}^{-1}\right)$ as compared to the IPSL model $\left(0.15 \mathrm{~K} \mathrm{decade}^{-1}\right)$. The appearance of a detectable change of soil moisture lags behind that of surface air temperature by several decades. This is due to the relatively smaller signalto-noise ratio for soil moisture variability as compared to that of the surface air temperature (see Delworth and Manabe, 1989). Furthermore, the smaller signal-to-noise ratio of soil moisture over the Indian region indicates relatively large natural interannual variability of summer monsoon precipitation (Fig. 10c). The IPSL model projection shows enhancement of monsoon precipitation and increase of soil moisture by the end of the 21st century (Fig. 10a, c). The decrease in monsoon precipitation over central India in the high-resolution LMDZ simulation is noticeable by the early 21 st century. It is also interesting to see that the high-resolution simulation indicates decrease of soil moisture from the middle to the end of the 21 st century over central India, despite a gradual revival of the projected monsoon precipitation by the mid 21 st century. From the above discussion, it is seen that the highresolution LMDZ simulations provide important value additions in terms of regional land surface response to changes in the South Asian monsoon.

\section{Conclusions}

We have used a state-of-the-art global climate model (LMDZ), with high-resolution telescopic zooming over South Asia, to investigate the regional land-surface response to changing climate and declining summer monsoon rains observed during the last few decades. This high-resolution climate model captures well the distribution of the mean monsoon rainfall and circulation features (Sabin et al., 2013). It is also noted that the high-resolution LMDZ model, which is coupled to a sophisticated land-surface parameterization scheme, displays a consistent surface water balance over the South Asian region - which is essential for making reliable assessments of the regional hydrological response to monsoonal changes. In the present work, we have performed two long-term simulation experiments, with and without anthropogenic forcing, for the historical period 1886-2005; and one future projection following the RCP4.5 scenario.

The results from our study suggest that the declining trend of monsoon precipitation over South Asia and weakening of large-scale summer monsoon circulation during the post- 
1950s are largely influenced by the anthropogenic forcing. It is found that the model simulated response to anthropogenic forcing shows an increase of surface temperature over the Indian region at a rate of $1.1^{\circ} \mathrm{C}(55 \mathrm{yr})^{-1}$, a decline of summer monsoon precipitation at a rate of $0.8 \mathrm{~mm} \mathrm{~d}^{-1}(55 \mathrm{yr})^{-1}$ and a corresponding reduction of soil moisture at a rate of $14 \mathrm{~mm}(55 \mathrm{yr})^{-1}$. The simulated decrease of mean monsoon precipitation over the Indian region during the post-1950s is accompanied by a weakening of large-scale monsoon circulation and is consistent with observations (Krishnan et al., 2013). The results of a future climate projection using medium scenario (RCP 4.5) shows likely continuation of the drying trend in monsoon rainfall and noticeable decrease of soil moisture till the end of the 21 st century. The present high-resolution simulations are scientifically interesting, particularly given that only some of the CMIP5 models driven with same scenario generally show a decrease in mean precipitation over the Indian region, associated with large uncertainties (Chaturvedi et al., 2012).

The declining monsoonal rains and the associated hydroclimatic changes can have profound implications for crop production and socio-economic activities in the region. Our findings from the high-resolution LMDZ simulations suggest that persistent decrease of monsoon rainfall and soil moisture over the Indian region has a significant impact on the regional land surface hydrology. The simulations show that a decrease of soil moisture over the Indian land region by $5 \%$ during 1951-2005 is accompanied by a decrease of ET by 9.5\%. It is noticed that the ET reduction and SM drying, over the Indian land points, are significantly correlated even under conditions of increasing surface incident short-wave radiation trends, implying that SM drying plays a dominant role in ET reduction in the region. While this study is based on a single realization, the realism of the high-resolution simulation enhances our confidence in interpreting the land-surface hydrological response to climate change and declining monsoons. We also realize that uncertainty quantification in land surface hydrological response to monsoonal changes at subregional scales, requires ensembles of high-resolution simulations. This is a topic of future research and beyond the scope of the present study.

Acknowledgements. Authors thank Director, IITM for extending all support for this research work. IITM is supported by Ministry of Earth Sciences, Government of India, New Delhi. The figures are prepared using GrADS. M. V. S. Ramarao is financially supported by the Indian Institute for Human Settlements (IIHS) through the Adaptation at Scale in Semi-Arid Regions (ASSAR) consortia of the Collaborative Adaptation Research initiative in Africa and Asia (CARIAA).This work is partially supported under the NORINDIA Project 216576/e10. We acknowledge the World Climate Research Programme's Working Group on Coupled Modelling, which is responsible for CMIP, and we thank the IPSL climate modelling group for producing and making available their model output. We thank the two anonymous reviewers and the editor for providing valuable reviews.

Edited by: G. Bala

\section{References}

Abish, B., Joseph, P. V., and Johannessen, O. M.: Weakening trend of the tropical easterly jet stream of the boreal summer monsoon season 1950-2009, J. Clim., 26, 9408-9414, doi:10.1175/JCLID-13-00440.1, 2013.

Bindoff, N.L., Stott, P., AchutaRao, K., Allen, M., Gillett, N., Gutzler, D., Hansingo, K., Hegerl, G., Hu, Y., Jain, S., Mokhov, I., Overland, J., Perlwitz, J., Sebbari, R., and Zhang, X.: Detection and Attribution of Climate Change: from Global to Regional, In: Climate Change 2013: The Physical Science Basis. Contribution of Working Group I to the Fifth Assessment Report of the Intergovernmental Panel on Climate Change, edited by: Stocker, T. F., Qin, D., Plattner, G.-K., Tignor, M., Allen, S. K., Boschung, J., Nauels, A., Xia, Y., Bex, V., and Midgley, P. M., Cambridge University Press, Cambridge, UK and New York, NY, USA, 867952, 2013.

Bollasina, M. A., Ming, Y., and Ramaswamy, V.: Anthropogenic Aerosols and the Weakening of the South Asian Summer Monsoon, Science., 334, 502-505, doi:10.1126/science.1204994, 2011.

Chaturvedi, R. K., Joshi, J., Jayaraman, M., Bala, G., and Ravindranath, N. H.: Multi-model climate change projections for India under representative concentration pathways, Curr. Sci., 103, 791-802, 2012.

Chung, C. E. and Ramanathan, V.: Weakening of north Indian SST gradients and the monsoon rainfall in India and the Sahel, J. Clim., 19, 2036-2045, doi:10.1175/JCLI3820.1, 2006.

Collins, M., AchutaRao, K., Ashok, K., Bhandari, S., Mitra, A. K., Prakash, S., Srivasatva, R., and Turner, A.: Observational challenges in evaluating climate models, Nat. Clim. Change, 3, 940941, doi:10.1038/nclimate2012, 2013.

Dee, D. P. and Uppala, S.: Variational bias correction of satellite radiance data in the ERA-Interim reanalysis, Q. J. Roy. Meteor. Soc., 135, 1830-1841, doi:10.1002/qj.493, 2009.

Dee, D. P., Uppala, S. M., Simmons, A. J., Berrisford, P., Poli, P., Kobayashi, S., Andrae, U., Balmaseda, M. A., Balsamo, G., Bauer, P., Bechtold, P., Beljaars, A. C. M., van de Berg, L., Bidlot, J., Bormann, N., Delsol, C., Dragani, R., Fuentes, M., Geer, A. J., Haimberger, L., Healy, S. B., Hersbach, H., Hólm, E. V., Isaksen, L., Kållberg, P., Köhler, M., Matricardi, M., McNally, A. P., Monge-Sanz, B. M., Morcrette, J.-J., Park, B.-K., Peubey, C., de Rosnay, P., Tavolato, C., Thépaut, J.-N., and Vitart, F.: The ERA-Interim reanalysis: configuration and performance of the data assimilation system, Q. J. Roy. Meteor. Soc., 137, 553-597. doi:10.1002/qj.828, 2011.

Delworth, T. L. and Manabe, S.: The influence of potential evaporation on the variabilities of simulated soil wetness and climate, J. Clim., 1, 523-547, 1988.

Delworth, T. L. and Manabe, S.: The Influence of soil wetness on near-surface atmospheric variability, J. Clim., 2, 1447-1462, 1989.

De Rosnay, P. and Polcher, J.: Modelling root water uptake in a complex land surface scheme coupled to a GCM, Hydrol. Earth Syst. Sci., 2, 239-255, doi:10.5194/hess-2-239-1998, 1998. 
Ducoudré, N. I., Laval, K. and Perrier, A.: SECHIBA, a New Set of Parameterizations of the Hydrologic Exchanges at the Land-Atmosphere Interface within the LMD Atmospheric General Circulation Model, J. Clim., 6, 248-273, doi:10.1175/15200442(1993)006<0248:SANSOP>2.0.CO;2, 1993.

Dufresne, J.-L., Foujols, M.-A., Denvil, S., Caubel, A., Marti, O., Aumont, O., Balkanski, Y., Bekki, S., Bellenger, H., Benshila, R., Bony, S., Bopp, L., Braconnot, P., Brockmann, P., Cadule, P., Cheruy, F., Codron, F., Cozic, A., Cugnet, D., de Noblet, N., Duvel, J.-P., Ethé, C., Fairhead, L., Fichefet, T., Flavoni, S., Friedlingstein, P., Grandpeix, J.-Y., Guez, L., Guilyardi, E., Hauglustaine, D., Hourdin, F., Idelkadi, A., Ghattas, J., Joussaume, S., Kageyama, M., Krinner, G., Labetoulle, S., Lahellec, A., Lefebvre, M.-P., Lefevre, F., Levy, C., Li, Z. X., Lloyd, J., Lott, F., Madec, G., Mancip, M., Marchand, M., Masson, S., Meurdesoif, Y., Mignot, J., Musat, I., Parouty, S., Polcher, J., Rio, C., Schulz, M., Swingedouw, D., Szopa, S., Talandier, C., Terray, P., Viovy, N., and Vuichard, N.: Climate change projections using the IPSL-CM5 Earth System Model: from CMIP3 to CMIP5, Clim. Dynam., 40, 2123-2165, doi:10.1007/s00382-012-1636-1, 2013.

Douville, H., Royer, J.-F., Polcher, J., Cox, P., Gedney, N., Stephenson, D. B, and Valdes, P. J.: Impact of doubling $\mathrm{CO}_{2}$ on the Asian summer monsoon: robust versus model-dependent responses, J. Meteorol. Soc. Jpn., 78, 421-439, 2000.

Fan, F., Mann, M. E., Lee, S., and Evans, J. L.: Observed and modeled changes in the South Asian summer monsoon over the historical period, J. Clim., 23, 5193-5205, doi:10.1175/2010JCLI3374.1, 2010.

Flato, G., Marotzke, J., Abiodun, B., Braconnot, P., Chou, S.C., Collins, W., Cox, P., Driouech, F., Emori, S., Eyring, V., Forest, C., Gleckler, P., Guilyardi, E., Jakob, C., Kattsov, V., Reason C., and Rummukainen, M.: Evaluation of Climate Models, in: Climate Change 2013: The Physical Science Basis. Contribution of Working Group I to the Fifth Assessment Report of the Intergovernmental Panel on Climate Change, edited by: Stocker, T. F., Qin, D., Plattner, G.-K., Tignor, M., Allen, S. K., Boschung, J., Nauels, A., Xia, Y., Bex, V., and Midgley, P. M., Cambridge University Press, Cambridge, UK and New York, NY, USA, 741866, doi:10.1017/CBO9781107415324.020, 2013.

Guhathakurta, P., Rajeevan, M.: Trends in the rainfall pattern over India, National climate Centre (NCC) Research Report No. 2, 1-23, India. Meteor. Department, Pune, 2006.

Harris, I., Jones. P. D., Osborn, T. J., and Lister, D. H.: Updated high-resolution grids of monthly climatic observations - the CRU TS3.10 Dataset, Int. J. Climatol., 34, 623-642, doi:10.1002/joc.3711, 2014.

Hasson, S., Lucarini, V., and Pascale, S.: Hydrological cycle over South and Southeast Asian river basins as simulated by PCMDI/CMIP3 experiments, Earth Syst. Dynam., 4, 199-217, doi:10.5194/esd-4-199-2013, 2013.

Hourdin, F., Musat, I., Bony, S., Braconnot, P., Codron, F., Dufresne, J. L., Fairhead, L., Filiberti, M. A., Friedlingstein, P., Grandpeix, J. Y., Krinner, G., LeVan, P., Li, Z. X., and Lott, F.: The LMDZ4 general circulation model: Climate performance and sensitivity to parametrized physics with emphasis on tropical convection, Clim. Dynam., 27, 787-813, doi:10.1007/s00382006-0158-0, 2006.
Huntington, T. G.: Evidence for intensification of the global water cycle: Review and synthesis, J. Hydrol., 319, 83-95, 2006.

Hurtt, G., Chini, L., Frolking, S., Betts, R., Feddema, J., Fischer, G., Fisk, J., Hibbard, K., Houghton, R., Janetos, A., Jones, C., Kindermann, G., Kinoshita, T., Klein Goldewijk, K., Riahi, K., Shevliakova, E., Smith, S., Stehfest, E., Thomson, A., Thornton, P., van Vuuren, D., and Wang, Y.: Harmonization of land-use scenarios for the period 1500-2100: 600 years of global gridded annual land-use transitions, wood harvest, and resulting secondary lands. Climatic Change, 109, 117-161, doi:10.1007/s 10584-0110153-2, 2011.

Jourdain, N. C., Gupta, A. Sen, Taschetto, A. S., Ummenhofer, C. C., Moise, A. F., and Ashok, K.: The Indo-Australian monsoon and its relationship to ENSO and IOD in reanalysis data and the CMIP3/CMIP5 simulations, Clim. Dynam., 41, 3073-3102, doi:10.1007/s00382-013-1676-1, 2013.

Jung, M., Reichstein, M., Ciais, P., Seneviratne, S. I., Sheffield, J., Goulden, M. L., Bonan, G., Cescatti, A., Chen, J., de Jeu, R., Dolman, a J., Eugster, W., Gerten, D., Gianelle, D., Gobron, N., Heinke, J., Kimball, J., Law, B. E., Montagnani, L., Mu, Q., Mueller, B., Oleson, K., Papale, D., Richardson, A. D., Roupsard, O., Running, S., Tomelleri, E., Viovy, N., Weber, U., Williams, C., Wood, E., Zaehle, S., and Zhang, K.: Recent decline in the global land evapotranspiration trend due to limited moisture supply, Nature, 467, 951-954, doi:10.1038/nature09396, 2010.

Kim, J., Sanjay, J., Mattmann, C., Boustani, M., Ramarao, M. V. S., Krishnan, R., and Waliser, D.: Uncertainties in estimating spatial and interannual variations in precipitation climatology in the India-Tibet region from multiple gridded precipitation datasets, Int. J. Climatol., doi:10.1002/joc.4306, 2015.

Kitoh, A., Yukimoto, S., Noda, A., and Motoi, T.:Simulated changes in the Asian summer monsoon at times of increased atmospheric $\mathrm{CO}_{2}$, J. Meteor. Soc. Jpn., 75, 1019-1031, 1997.

Krinner, G., Viovy, N., de Noblet-Ducoudré, N., Ogée, J., Polcher, J., Friedlingstein, P., Ciais, P., Sitch, S., and Prentice, C.: A dynamic global vegetation model for studies of the coupled atmosphere-biosphere system, Global Biogeochem. Сy., 19, GB1015, doi:10.1029/2003GB002199, 2005.

Krishnan, R., Sabin, T. P., Ayantika, D. C., Kitoh, A., Sugi, M., Murakami, H., Turner, A. G., Slingo, J. M., and Rajendran, K.: Will the South Asian monsoon overturning circulation stabilize any further?, Clim. Dynam., 40, 187-211, doi:10.1007/s00382012-1317-0, 2013.

Kumar, K. N., Rajeevan, M., Pai, D. S., Srivastava, A. K., and Preethi, B.: On the observed variability of monsoon droughts over India, Weather Clim. Extrem., 1, 42-50, doi:10.1016/j.wace.2013.07.006, 2013.

Loveland, T. R., Reed, B. C., Brown, J. F., Ohlen, D. O., Zhu, Z., Yang, L., and Merchant, J. W.: Development of a global land cover characteristics database and IGBP DISCover from $1 \mathrm{~km}$ AVHRR data, Int. J. Remote. Sens., 21, 1303-1330, doi:10.1080/014311600210191, 2000.

Maraun, D.: Nonstationarities of regional climate model biases in European seasonal mean temperature and precipitation sums, Geophys. Res. Lett., 39, L06706, doi:10.1029/2012GL051210, 2012.

Meinshausen, M., Smith, S. J., Calvin, K. V., Daniel, J. S., Kainuma, J. F., Lamarque, M., K., Montzka, S. A., Raper, S. C. B., Ri- 
ahi, K., Thomson, A.M., Velders, G. J. M., and van Vuuren, D.: The RCP greenhouse gas concentrations and their extension from 1765 to 2300 , Clim. Change, 109, 213-241, doi:10.1007/s10584011-0156-z, 2011.

Padmakumari, B., Jaswal, A. K., and Goswami, B. N.: Decrease in evaporation over the Indian monsoon region: Implication on regional hydrological cycle, Clim. Change, 121, 787-799, doi:10.1007/s10584-013-0957-3, 2013.

Pai, D. S., Sridhar Latha, Rajeevan, M., Sreejith, O. P., Satbhai, N. S., and Mukhopadhyay, B.: Development of a new high spatial resolution $\left(0.25^{\circ} \times 0.25^{\circ}\right)$ long period (1901-2010) daily gridded rainfall data set over India and its comparison with existing data sets over the region, Mausam, 65, 1-18, 2014.

Rajendran, K., Kitoh, A., Srinivasan, J., Mizuta, R., and Krishnan, R.: Monsoon circulation interaction with Western Ghats orography under changing climate projection by a 20-km mesh AGCM, Theor. Appl. Climatol., 110, 555-571, doi:10.1007/s00704-0120690-2, 2012.

Rodell, M., Houser, P. R., Jambor, U., Gottschalck, J., Mitchell, K., Meng, C.-J., Arsenault, K., Cosgrove, B., Radakovich, J., Bosilovich, M., Entin, J. K., Walker, J. P., Lohmann, D., and Toll, D.: The Global Land Data Assimilation System, Bull. Am. Meteorol. Soc., 85, 381-394, 2004.

Sabin, T. P., Krishnan, R., Ghattas, J., Denvil, S., Dufresne, J. L., Hourdin, F., and Pascal, T.: High resolution simulation of the South Asian monsoon using a variable resolution global climate model, Clim. Dynam., 41, 173-194, doi:10.1007/s00382-0121658-8, 2013.

Saha, A., Ghosh, S., Sahana, A. S., and Rao, E. P.: Failure of CMIP5 climate models in simulating post-1950 decreasing trend of Indian monsoon, Geophys. Res. Lett., 41, 7323-7330, doi:10.1002/2014GL061573, 2014.

Seneviratne, S. I., Corti, T., Davin, E. L., Hirschi, M., Jaeger, E. B., Lehner, I., Orlowsky, B., and Teuling, A. J.: Investigating soil moisture-climate interactions in a changing climate: A review, Earth-Science Rev., 99, 125-161, doi:10.1016/j.earscirev.2010.02.004, 2010.

Seneviratne, S. I., Lüthi, D., Litschi, M., and Schär, C.: Landatmosphere coupling and climate change in Europe, Nature, 443, 205-209, doi:10.1038/nature05095, 2006.

Seneviratne, S. I., Pal, J. S., Eltahir, E. A. B., and Schär, C.: Summer dryness in a warmer climate: A process study with a regional climate model, Clim. Dyn., 20, 69-85, doi:10.1007/s00382-0020258-4, 2002.

Singh, D., Tsiang, M., Rajaratnam, B., and Diffenbaugh, N. S.: Observed changes in extreme wet and dry spells during the South Asian summer monsoon season, Nat. Clim. Change, 4, 1-6, doi:10.1038/nclimate2208, 2014.
Szopa, S., Balkanski, Y., Schulz, M., Bekki, S., Cugnet, D., Fortems-Cheiney, A., Turquety, S., Cozic, A., Deandreis, C., Hauglustaine, D., Idelkadi, A., Lathie're, J., Marchand, M., Yan, N., and Dufresne, J. L.: Aerosol and ozone changes as forcing for climate evolution between 1850 and 2100, Clim. Dynam., 40, 2223-2250, doi:10.1007/s00382-012-1408-y, 2013.

Tanaka, H. L., Ishizaki, N., and Kitoh, A.: Trend and interannual variability of Walker, monsoon and Hadley circulations defined by velocity potential in the upper troposphere, Tellus, 56A, 250269, 2004.

Taylor, K. E.: Summarizing multiple aspects of model performance in a single diagram, J. Geol. Res., 106, 7183-7192, doi:10.1029/2000JD900719, 2001.

Taylor, K. E., Stouffer, R. J., and Meehl, G. A.: An overview of CMIP5 and the experiment design, Bull. Am. Meteorol. Soc., 93, 485-498, doi:10.1175/BAMS-D-11-00094.1, 2012.

Teuling, A. J., Hirschi, M., Ohmura, A., Wild, M., Reichstein, M., Ciais, P., Buchmann, N., Ammann, C., Montagnani, L., Richardson, A. D., Wohlfahrt, G., and Seneviratne, S. I.: A regional perspective on trends in continental evaporation, Geophys. Res. Lett., 36, 1-5, doi:10.1029/2008GL036584, 2009.

Ueda, H., Iwai, A., Kuwako, K., and Hori, M. E.: Impact of anthropogenic forcing on the Asian summer monsoon as simulated by eight GCMs, Geophys. Res. Lett., 33, L06703, doi:10.1029/2005GL025336, 2006.

Veechi, G. A., Soden, B. J., Wittenberg, A. T., Held, I. M., Leetma, A., and Harrison, M. J.: Weakening of tropical Pacific atmospheric circulation due to anthropogenic forcing, Nature, 441, 73-76, 2006.

Wetherald, R. T. and Manabe, S.: Detectability of summer dryness caused by greenhouse warming, Clim. Change, 43, 495-511, 1999.

Xie, P. and Arkin, P. A.: Global precipitation: A 17-year monthly analysis based on gauge observations, satellite estimates, and numerical model outputs, B. Am. Meteor. Soc., 78, 2539-2558, 1997.

Yatagai, A., Kamiguchi, K., Arakawa, O., Hamada, A., Yasutomi, N., and Kitoh, A.: APHRODITE: Constructing a long-term daily gridded precipitation dataset for Asia based on a dense network of rain gauges, B. Am. Meteor. Soc., 93, 1401-1415, doi:10.1175/BAMS-D-11-00122.1, 2012. 